\title{
SOFT TISSUE HEALING AROUND IMMEDIATELY PLACED DENTAL IMPLANTS AUGMENTED WITH AMNIOTIC CHORION MEMBRANE VERSUS CONNECTIVE TISSUE GRAFT (A CLINICAL AND HISTOLOGICAL STUDY)
}

\author{
Norai A. Zayed ${ }^{1} B D S$, Ahmed M. Hommos $P h D$, Sahar SH. Karam ${ }^{3} P h D$, Rania A. Fahmy ${ }^{4} P h D$.
}

\section{ABSTRACT}

INTRODUCTION: The Amnion Chorion Membrane (ACM) has favorable regenerative properties which facilitates its use for covering immediate dental implants.

OBJECTIVES: To evaluate clinically and histologically the effect of Amnion Chorion membrane in augmenting immediately placed dental implants compared to connective tissue graft (CTG)

MATERIALS AND METHODS: This study was conducted clinically on eighteen upper hopeless anterior/premolar teeth scheduled for extraction and immediate implant placement. Patients were divided into two groups: in the first group, nine immediate implants were covered with ACM, and in the second group nine immediate implants were covered with CTG. Keratinized mucosal width (KMW), keratinized mucosal thickness (KMT) and healing score were recorded for both groups at 7,14 , 30 and 90 days

RESULTS: The KMT showed an increase by $26 \%$ in the test group while in the control group it decreased by $6.5 \%$ by the end of the study period. Regarding the healing scores both groups showed marked improvement throughout the study, lower values of healing scores were noted in the test group. Clinical results were confirmed by histological examination which revealed that oral mucosa of both groups showed parakeratinized gingival epithelium. The connective tissue of the test group showed more regularly arranged ,thick bundles.

CONCLUSIONS Both treatment modalities were satisfactory but the ACM offered more positive results concerning the mucosal thickness and healing scores.

KEYWORDS: Immediate implants, ACM, Connective tissue graft, Soft tissue

1. B.D.S. Faculty of Dentistry Pharos University and Instructor of Periodontology, Oral Medicine, Diagnosis and Radiology, Pharos University, Alexandria, Egypt.

2. Professor of Periodontology, Oral Medicine, Diagnosis and Radiology, Faculty of Dentistry Alexandria University

3. Professor of Oral Biology, Faculty of Dentistry Alexandria University

4. Lecturer of Periodontology, Oral Medicine, Diagnosis and Radiology, Faculty of Dentistry Alexandria University

\section{INTRODUCTION}

Immediate implant placement, also known as Type I placement, is defined as the placement of an implant immediately after tooth extraction (1). The main advantage of immediate implant placement is the reduction of the healing time which leads to earlier prosthodontic therapy. In addition the width and height of the alveolar bone is preserved, and thus presenting aesthetic and functional benefits (2).

Mucogingival conditions around extraction sockets , especially narrow zones of keratinized gingiva, may be unfavorable to primary closure . This may require mucogingival surgeries to correct such soft tissue defects (3). A variety of techniques have been introduced to achieve primary closure over immediately placed dental implants. Bowers and Donahue (1988) (3) described a technique using periosteal releasing and vertical incisions to achieve sufficient mobility of the buccal flap. The buccal flap was then approximated and sutured to the palatal one. This will result in moving the existing buccal mucosa coronally leading to discrepancy between the mucogingival junction of the treated site and adjacent sites .

In 1995 Edel (3) suggested the use of connective tissue graft as a biologic membrane to cover the residual alveolar bone defect associated with immediate implants. It was shown to improve the local metabolic environment of the superficial soft tissues and preserve the keratinized tissue, thus obtaining a satisfactory peri -implant marginal sealing. Studies have shown that connective tissue graft has its own limitations including; requiring an additional surgical site and necrosis of the graft leading to inferior esthetic outcomes (4).

Lazzara (5) was the first to adopt expanded polytetrafluoroethylene (e-PTFE) membranes to augment fresh extraction sites after immediate implantation. The rationale for using barrier membranes is to retain a space defect adjacent to the implant to facilitate clot formation, retention, and stabilization. In addition, the membrane is intended to prevent connective tissue collapse and its contact with the implant surface. Thus, apical proliferation of epithelium is prevented in favor of osteogenic cells, increasing the likelihood of bone regeneration around the implant's coronal portion. The limitation of this membrane is that its exposure may lead to complications, such as infection, bone loss, and even implant loss.

Amniotic Chorion membrane (ACM) has been proposed to be used in covering immediate dental implants. ACM is the inner most lining of the fetal membrane that is in contact with the developing fetus. The ACM has numerous advantages owing to its structure and composition. The extracellular matrix comprises collagen Types I, III, IV, V, and VI and cell-adhesion bioactive factors, such as 
fibronectin and laminin (6). Collagen is well tolerated and bioabsorbable, has hemostatic properties, and encourages migration of adjacent autogenous connective tissue. Fibronectin is involved in many cellular processes, including tissue repair, blood clotting, cell migration, and adhesion (7). Laminin and Laminin-5 has a high affinity for binding epithelial cells, and in contrast to traditionally available membranes (8). This biological factor allows the ACM to be left exposed to the oral environment.

It has been also proven that the ACM has a potential for regeneration in periodontology as the matrix of the chorion contains abundant growth factors, such as keratinocyte growth factor, basic fibroblast growth factor, and transforming growth factor- $\beta$, that promote periodontal regeneration. and provide a natural environment for accelerated healing (9). It was used in socket preservation, guided tissue regeneration and guided bone regeneration. Furthermore, the ability of this allograft to self-adhere eliminates the need for suturing (10).

The present study was performed to compare and evaluate clinically and histologically the soft tissue healing around immediately placed dental implants augmented with Amnion Chorion Membrane versus sub epithelial connective tissue graf

\section{MATERIALS AND METHODS}

The present study was conducted on eighteen upper anterior/premolar hopeless teeth that have been scheduled for extraction attending the outpatient clinic of the Periodontology and Oral Medicine Department, Faculty of Dentistry, Alexandria University.

The study was approved by the ethical committee at the Faculty of Dentistry, Alexandria University. All patients received both oral and written information about the study protocol and signed their informed consent before agreeing to participate in the study.

\section{Inclusion criteria :}

The patients were systemically healthy (American Society of Anesthesiologists I or II) (11) with age ranging between (20-40) years.

All patients had a tooth in the maxillary premolar or anterior region requiring extraction due to one of the following reasons:

1- Badly decayed tooth that cannot be restored.

2- Tooth with failed endodontic treatment.

3- Tooth with longitudinal fracture.

\section{Exclusion criteria}

Unstable systemic diseases precluding surgical procedures, compromised healing conditions (e.g., uncontrolled diabetes mellitus or human immunodeficiency virus infection), bone disorders (hyperparathyroidism, osteoporosis, or Paget's disease), smoking more than 10 cigarettes per day, long-term ( $>2$ weeks) use of medications that affect the periodontium eg: (anti-inflammatories, steroids, or bisphosphonates) in the past 3 months. Pregnant or lactating women. Besides, an O'Leary plaque score > $20 \%$ (12) and localised or generalised aggressive periodontitis

\section{Pre surgical phase}

1. The assessment of oral hygiene condition of the patient, the condition of the tooth or remaining root to be extracted, the recipient site and the inter-occlusal space.

2. Radiographic evaluation: (Cone beam computed tomography (C.B.C.T) ) was performed at the first visit to evaluate:

- Location of implant recipient site away from any vital anatomical structures.

- Presence of adequate bone quantity and quality

3- Impression for the upper jaw of the patient using alginate impression material (Hydrogum, Zhermack, Italy) to fabricate transparent acrylic stent for measurement of the keratinized -mucosal thickness.

4. Oral hygiene instructions were given to the patients which include teeth brushing using a proper technique 3 times daily.

\section{Surgical Phase}

\section{Tooth extraction}

- The tooth was atraumatically extracted using a periotome (Nordent, USA) which acts by severing the periodontal ligaments avoiding bucco-palatal movements to avoid damage to the buccal plate of bone.

\section{Implant Placement}

- Drilling with low speed (1000 rpm), high torque and internal irrigation with normal saline to maintain bone vitality was performed to depth of $3 \mathrm{~mm}$ beyond the socket.

- Implant ( Dio implant, Korea ) was threaded into the bone using a ratchet as recommended by the manufacturer.

- The implant was seated subcrestally $2 \mathrm{~mm}$ below the crest of the socket wall.

- Adequate primary stability was obtained.

\section{For test group}

ACM ( Bioxclude, Snoasis Medical , USA ) was applied to augment the immediate implant site extending 2-3 mm under the buccal and palatal flaps leaving $2 \mathrm{~mm}$ of it exposed (Figure 1).

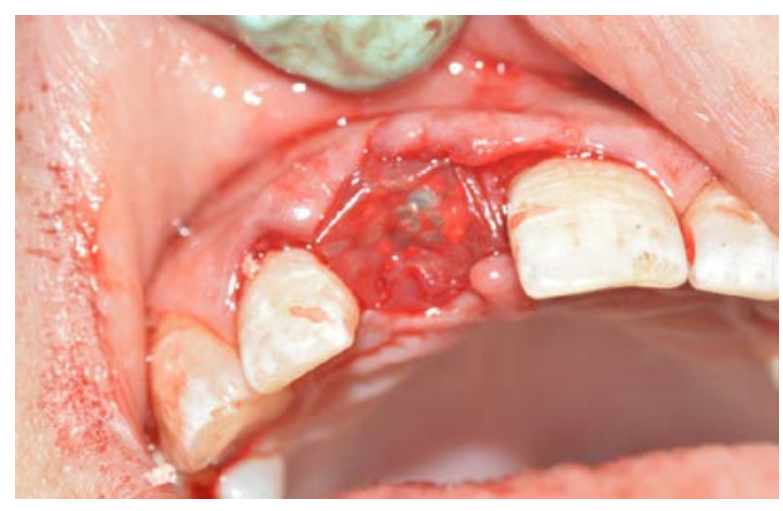

Figure 1: ACM membrane placed over the implant and tucked beneath the partial thickness buccal and palatal flaps.

Flap was sutured back into position to provide proper adaptation of the ACM by crossed over -horizontal mattress sutures using 4-0 non resorbable sutures leaving $2 \mathrm{~mm}$ of 
the ACM exposed . There was no coronal advancement of the labial flap to maintain the integrity of the mucogingival line for good esthetics.

\section{For control group}

Connective tissue graft of approximately $1.5-2 \mathrm{~mm}$ thickness was harvested from the palate of the same site of implant placement, following local anesthesia. A "trap door" split thickness flap, consisting of 1 horizontal and 2 vertical incisions, was elevated (13) (Figure 2).

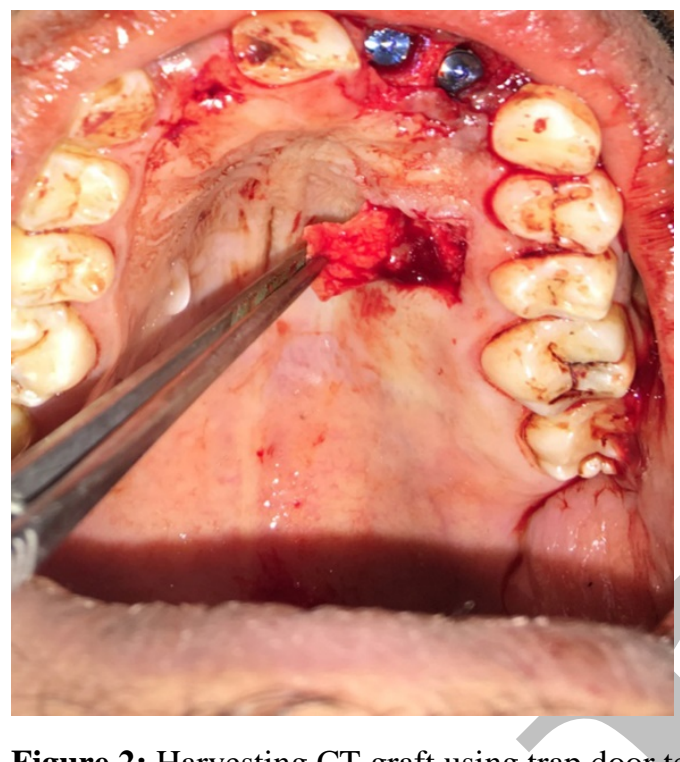

Figure 2: Harvesting CT graft using trap door technique.

The underlying connective tissue was harvested using a periosteal elevator.

Connective tissue graft was secured over the implant (Figure 3)

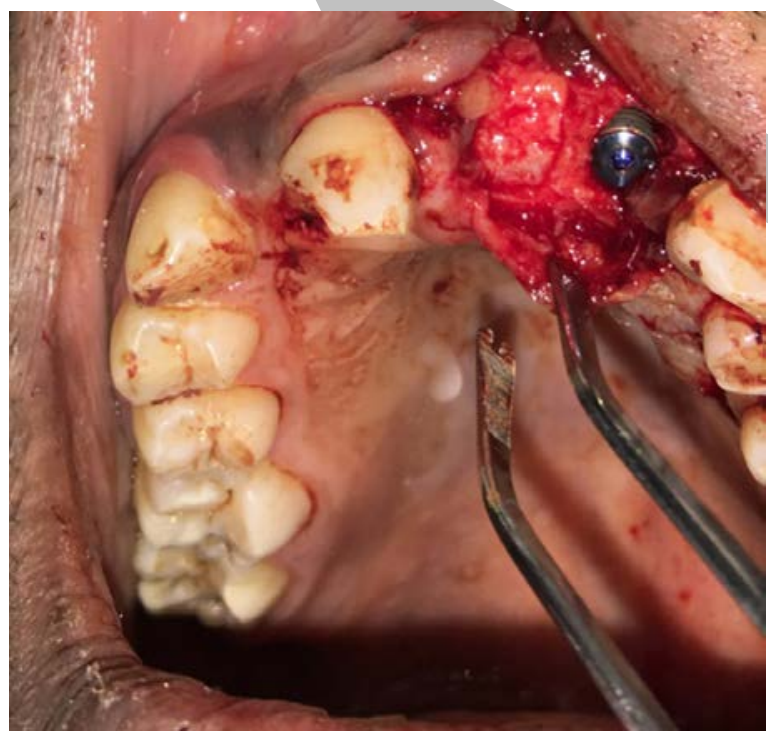

Figure 3: CT graft covering implant replacing upper left central incisor.

using 4-0 non resorbable horizontal mattress sutures. Closure of the flap by interrupted sutures was performed if needed.

\section{Follow up phase}

\section{I) Clinical evaluation}

Follow up was performed at base line, seven days, fourteen days, one month, and three months respectively for evaluating:

1. Keratinized mucosal width measured using William's periodontal probe at baseline, one and three months.

2. Keratinized mucosal thickness measured, at baseline, one month and three months, using a stent where holes were located at the midpoint on the mid-facial surface of the mucosa. A periodontal probe was be inserted through the hole perforating the mucosa all the way to the cortical bone.

3. Healing score was taken according to (AL-Mashhadani, 2012) (16):

$4=\quad$ Necrotic Tissue (Eschar): black, brown, or tan tissue that adheres firmly to the wound bed

$3=$ Slough: yellow or white tissue that adheres to the wound bed

$2=$ Granulation Tissue: pink or beefy red tissue with a shiny, moist, granular appearance.

$1=$ Epithelial Tissue: for superficial ulcers, new pink or shiny tissue that grows in from the edges or as islands on the wound surface.

$0=$ Closed/Resurfaced: the wound is completely covered with epithelium.

\section{II) Histological evaluation}

A tissue sample $3 \mathrm{~mm}$ in size was obtained by a tissue punch during the second stage surgery to uncover the implant for abutment insertion (4 months). All specimens were labeled and fixed in 10\% neutral buffered formalin. After fixation, specimens were dehydrated in ascending concentrations of ethanol, cleared with xylene, infiltrated and embedded in paraffin wax. Thin sections of $5 \mu \mathrm{m}$ thick were cut using rotary microtome. Sections were stained with Haematoxylin and Eosin stains (H \& E) for general examination.

\section{Statistical analysis (15)}

Data were fed to the computer and analyzed using IBM SPSS software package version 20.0. (Armonk, NY: IBM Corp) (16). Qualitative data were described using number and percent. The Kolmogorov-Smirnov test was used to verify the normality of distribution Quantitative data were described using range (minimum and maximum), mean, standard deviation and median. Significance of the obtained results was judged at the $5 \%$ level

\section{RESULTS}

\section{Clinical evaluation (Figure 4)}

A significant regression in the KMWin the study group was realized after one month compared to baseline (from a mean of $5.73 \pm 0.71$ to a mean of $4.90 \pm 1.14)(p=0.34)$ followed by an insignificant increase to a mean of $4.96 \pm 1.21$ after three months. However, in the control group a decrease in the KMW was evident at one month with a mean $(4.77 \pm 1.36)$ and 3 months with a mean of $(4.73 \pm 1.40)$. This decrease was insignificant both at baseline to 1 month and from 1 month to 3 months. However, it was significant from baseline to 3 months $(p=0.049)$. On comparing both groups together no significant difference was realized throughout different studied periods (Table 1). 


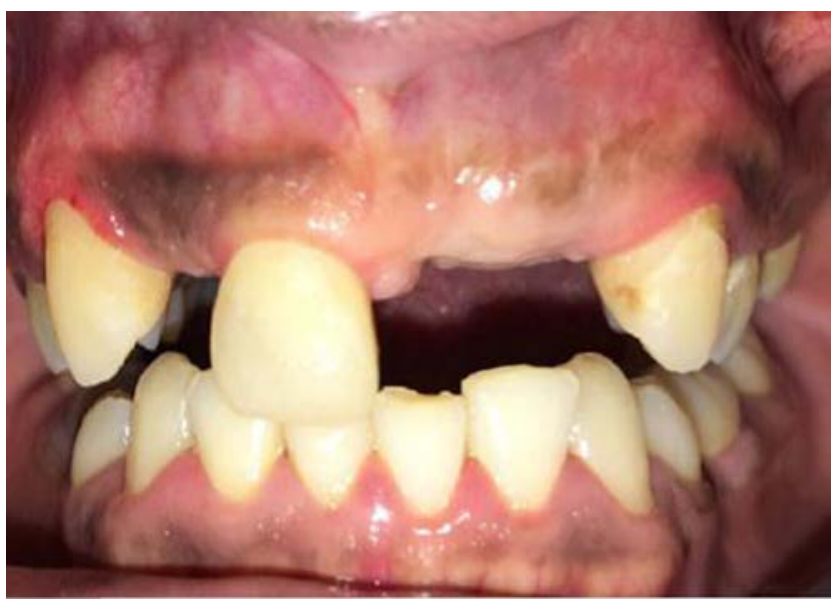

Figure 4: Three months follow up of a case where ACM used to cover immediate implant replacing upper left central incisor and CTG used to cover upper left lateral incisor. Note symmetry of the mucogingival line and increase thickness of tissue in place of the ACM.

Table (1): Comparison between the two studied groups with respect to keratinized mucosal width.(mm.)

\begin{tabular}{|c|c|c|c|c|}
\hline $\begin{array}{l}\text { Keratinized } \\
\text { mucosal width } \\
(\mathrm{mm} .)\end{array}$ & Baseline & 1 month & 3 months & $\mathbf{p}_{4}$ \\
\hline \multicolumn{5}{|l|}{$\begin{array}{l}\text { Test group } \\
(n=9)\end{array}$} \\
\hline Mean \pm SD & $5.73 \pm 0.71$ & $4.90 \pm 1.14$ & $4.96 \pm 1.21$ & \\
\hline Min. - Max. & $4.50-6.50$ & $3.50-6.30$ & $3.50-6.50$ & $0.006^{*}$ \\
\hline Median & 6.0 & 4.30 & 4.30 & \\
\hline Sig. & \multicolumn{3}{|c|}{$\mathrm{p}_{1}=0.034^{*}, \mathrm{p}_{2}=0.077, \mathrm{p}_{3}=0.724$} & \\
\hline \multicolumn{5}{|l|}{$\begin{array}{l}\text { Control group } \\
(n=9)\end{array}$} \\
\hline Mean \pm SD. & $5.47 \pm 0.84$ & $4.77 \pm 1.36$ & $4.73 \pm 1.40$ & \\
\hline Min. - Max. & $4.0-6.30$ & $3.0-6.30$ & $3.0-6.30$ & $0.009^{*}$ \\
\hline Median & 6.0 & 4.0 & 4.0 & \\
\hline Sig. & \multicolumn{3}{|c|}{$\mathrm{p}_{1}=0.099, \mathrm{p}_{2}=0.049^{*}, \mathrm{p}_{3}=0.814$} & \\
\hline $\mathbf{P}$ & 0.467 & 0.785 & 0.586 & \\
\hline
\end{tabular}

p: p values for Mann Whitney test for comparing between the two groups in each period

$\mathrm{p}_{1}$ : $\mathrm{p}$ value for comparing between Baseline and 1 month in each group

$\mathrm{p}_{2}$ : $\mathrm{p}$ value for comparing between Baseline and 3 months in each group

$\mathrm{p}_{3}$ : $\mathrm{p}$ value for comparing between 1 month and 3 months in each group

p4: p for Friedman test for comparing between the three periods in each group, Sig. bet. Periods was done using

Post Hoc Test (Dunn's multiple comparisons test)

*: Statistically significant at $\mathrm{p} \leq 0.05$

Concerning the study group, there was an increase in thickness of the keratinized mucosa from baseline to one month (from a mean of $3.56 \pm 1.59$ to a mean of $3.89 \pm 0.78$ ) and a decrease in thickness from one month to three months (from a mean of $3.89 \pm 0.78$ to a mean of $3.67 \pm 0.50$ ). However, there was no statistical significance difference between all studied periods with respect to this variable .
Moreover,in the control group there was a decrease in the keratinized mucosal thickness from baseline to one month (from a mean of $3.44 \pm 1.01$ to mean of $3.22 \pm 1.09$ ) which continued to decrease up till three months (from a mean of $3.22 \pm 1.09$ to a mean of $3.11 \pm 0.93$ ). There was no statistical significance between all studied periods (Table 2).

Table (2): Descriptive analysis of the studied cases with respect to keratinized mucosal thickness (in mm.)in two groups.

\begin{tabular}{|c|c|c|c|c|}
\hline $\begin{array}{c}\text { Keratinized } \\
\text { mucosal thickness } \\
\text { (mm.) }\end{array}$ & Baseline & 1 month & 3 months & $\mathbf{p}_{1}$ \\
\hline \multicolumn{5}{|l|}{ Test group $(n=9)$} \\
\hline Mean \pm SD. & $3.56 \pm 1.59$ & $3.89 \pm 0.78$ & $3.67 \pm 0.50$ & \multirow{3}{*}{0.540} \\
\hline Min. - Max & $1.0-6.0$ & $3.0-5.0$ & $3.0-4.0$ & \\
\hline Median & 3.0 & 4.0 & 4.0 & \\
\hline$\%$ of Change Baseline & & $\uparrow 34.26$ & $\uparrow 26.85$ & \\
\hline \% of Change & & \multicolumn{2}{|c|}{$\downarrow 4.44$} & \\
\hline \multicolumn{4}{|l|}{$\begin{array}{l}\text { Control group } \\
(n=9)\end{array}$} & \multirow{4}{*}{0.595} \\
\hline Mean \pm SL & $3.44 \pm 1.01$ & $3.22 \pm 1.09$ & $3.11 \pm 0.93$ & \\
\hline Min. - Max. & $3.0-6.0$ & $2.0-5.0$ & $2.0-4.0$ & \\
\hline Median & 3.0 & 3.0 & 3.0 & \\
\hline$\%$ of Change Baseline & & $\downarrow 2.78$ & $\downarrow 6.48$ & \\
\hline \% of Change & & & & \\
\hline $\mathbf{P}$ & 0.874 & 0.180 & 0.184 & \\
\hline
\end{tabular}

p: p value for Mann Whitney test for comparing between the two groups in each period

$\mathrm{p}_{1}$ : $\mathrm{p}$ for Friedman test for comparing between the three periods in each group

he keratinized mucosa in the study group increased in thickness by $34.26 \%$ and $26.85 \%$ from baseline to one month and baseline to three months, respectively. While on the other hand in the control group there was a decrease in thickness in the keratinized mucosa of $2.78 \%$ from baseline to one month which was $2.22 \%$ less than the decrease of $6.48 \%$ from baseline to 3 months (Table 2). On comparing both groups together there was no statistical significance between them.

Regarding the Healing score, there was an insignificant improvement in the study group from a healing score of $(3.0 \pm 0.0)$ at 7 days to a healing score of $(2.0 \pm 0.71)$ at 14 days, while it depicted a significant improvement to a score of $(0.56 \pm 0.53)$ at 30 days $\left(p=0.037^{*}\right)$ to reach an insignificant improvement of (score $0.0 \pm 0.0$ ) at complete healing at 90 days. However, in the control group , healing improved insignificantly from a score of $(2.78 \pm 0.44)$ at 7 days to a score of $(2.22 \pm 0.83)$ at 14 days which continued to improve insignificantly to a score of $(0.78 \pm 0.44)$ at 30 days to reach insignificant improvement (score $0.0 \pm 0.0$ ) at complete healing at 90 days. Healing improved significantly in both the study and control groups when comparing all periods of time together within the same group $\left(\mathrm{p}=<0.001^{*}\right)$ .When comparing both groups to each other, there was no statistical significant difference at any of the time intervals (Table 3). 
Table (3): Descriptive analysis of the studied cases according to healing score in two groups.

\begin{tabular}{|c|c|c|c|c|c|}
\hline Healing score & 7 days & 14 days & 30 days & 90 days & $\mathbf{p}_{1}$ \\
\hline \multicolumn{6}{|l|}{$\begin{array}{l}\text { Test group } \\
(\mathrm{n}=9)\end{array}$} \\
\hline $\begin{array}{l}\text { Min. - } \\
\text { Max. }\end{array}$ & $3.0-3.0$ & $1.0-3.0$ & $0.0-1.0$ & $0.0-0.0$ & \\
\hline $\begin{array}{l}\text { Mean } \pm \\
\text { SD. }\end{array}$ & $3.0 \pm 0.0$ & $2.0 \pm 0.71$ & $\begin{array}{c}0.56 \pm \\
0.53\end{array}$ & $0.0 \pm 0.0$ & $\begin{array}{l}<0.0 \\
01^{*}\end{array}$ \\
\hline Median & 3.0 & 2.0 & 1.0 & 0.0 & \\
\hline Sig. & \multicolumn{4}{|c|}{$\begin{aligned} & \mathrm{p}_{2}=0.297, \mathrm{p}_{3}=0.002^{*}, \mathrm{p}_{4} \\
&<0.001^{*}{ }^{,} \mathrm{p}_{5}=0.037^{*}, \mathrm{p}_{6}=0.001^{*}, \mathrm{p}_{7}=0.264\end{aligned}$} & \\
\hline \multicolumn{6}{|l|}{\begin{tabular}{||l} 
Control \\
$\operatorname{group}(n=9)$
\end{tabular}} \\
\hline $\begin{array}{l}\text { Min. - } \\
\text { Max. }\end{array}$ & $2.0-3.0$ & $1.0-3.0$ & $0.0-1.0$ & $0.0-0.0$ & \\
\hline $\begin{array}{l}\text { Mean } \pm \\
\text { SD. }\end{array}$ & $\begin{array}{c}2.78 \pm \\
0.44\end{array}$ & $\begin{array}{c}2.22 \pm \\
0.83\end{array}$ & $\begin{array}{c}0.78 \pm \\
0.44\end{array}$ & $0.0 \pm 0.0$ & \begin{tabular}{|c|}
$<0.0$ \\
$01^{*}$
\end{tabular} \\
\hline Median & 3.0 & 2.0 & 1.0 & 0.0 & \\
\hline Sig. & \multicolumn{4}{|c|}{$\begin{array}{c}\mathrm{p}_{2}=0.456, \mathrm{p}_{3}=0.007^{*}, \mathrm{p}_{4} \\
<0.001^{*}, \mathrm{p}_{5}=0.053, \mathrm{p}_{6}<0.001^{*}, \mathrm{p}_{7}=0.118\end{array}$} & \\
\hline $\mathbf{P}$ & 0.145 & 0.507 & 0.331 & 1.000 & \\
\hline
\end{tabular}

p: p values for Mann Whitney test for comparing between the two groups in each period

$\mathrm{p}_{1}$ : $\mathrm{p}$ for Friedman test for comparing between the three periods in each group, Sig. bet. Periods was done using Post Hoc Test (Dunn's multiple comparisons test)

$\mathrm{p}_{2}$ : $\mathrm{p}$ value for comparing between 7 days and 14 days in each group

$\mathrm{p}_{3}$ : $\mathrm{p}$ value for comparing between 7 days and 30 days in each group

p4: p value for comparing between 7 days and 90 days in each group

p5: p value for comparing between 14 days and 30 days in each group

$\mathrm{p}_{6}$ : $\mathrm{p}$ value for comparing between 14 days and 90 days in each group

p7: p value for comparing between 30 days and 90 days in each group

*: Statistically significant at $\mathrm{p} \leq 0.05$

\section{Histological Evaluation}

Concerning the control group, the epithelium was parakeratinized with long epithelial ridges. The collagen fibers in the deep layer of the lamina propria were less dense, not running in bundles and having undefined orientation than those in the study group. Less inflammatory cells were noted than in the study group (Figure 5).

Regarding the study group, parakeratinized epithelium facing the oral cavity with long epithelial ridges seen extending deep into the underlying lamina propria. The superficial papillary layer of the lamina propria contained thin loosely arranged fibers while in the deep reticular layer the collagen fibers were arranged in thick bundles showing infiltration of inflammatory cells (Figure 6).

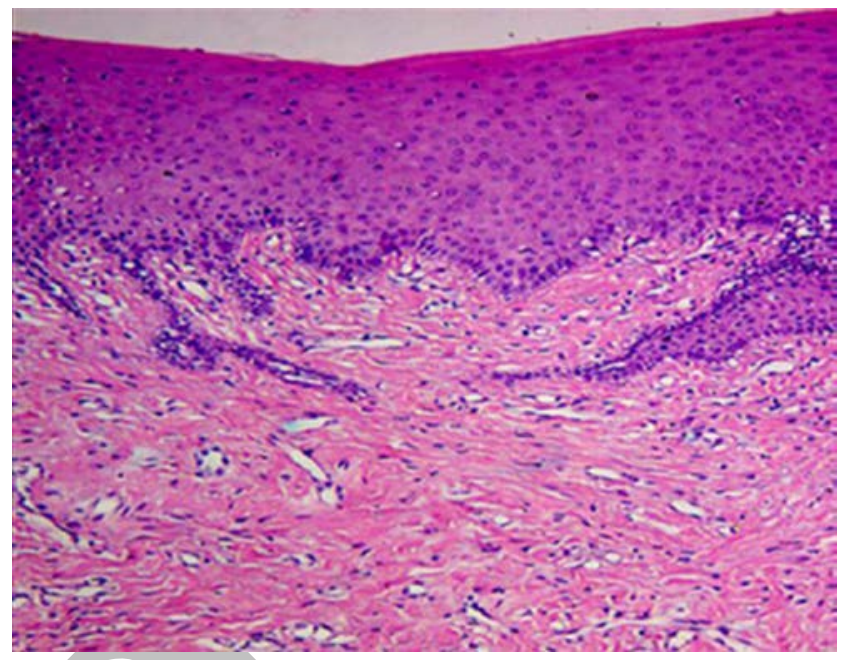

Figure 5: A photomicrograph of control group showing: thick Parakeratinized stratified squamous epithelium (basal cell layer, prickle cell layer, granular cell layer, and parakeratinous layer with pyknotic nuclei) with various length rete pegs (arrows). Note: the lamina propria showing loose fibers arrangement in the papillary layer and dense arrangement in the reticular layer. Inflammatory cell infiltration can be observed (H\&E stain, Orig Mag x100).

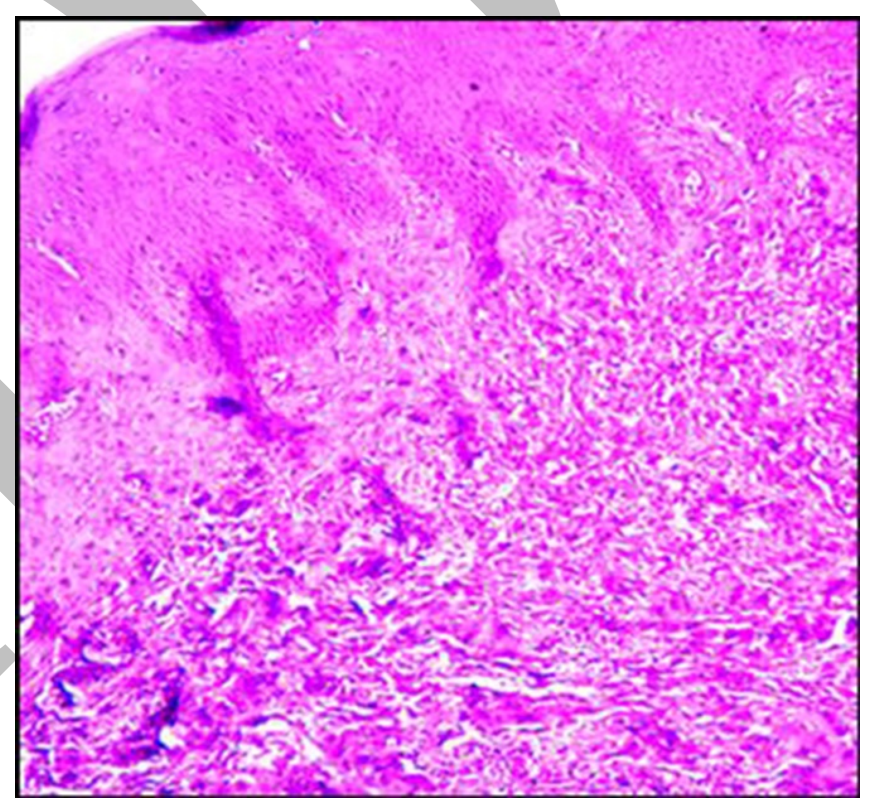

Figure 6: A photomicrograph of the study group showing parakeratinized epithelium (basal cell layer, prickle cell layer, granular cell layer, and parakeratinous layer with pyknotic nuclei) with long epithelial ridges and high connective tissue papillae ( H \& E stain, orig. Mag. X100).

\section{DISCUSSION}

The outcome of placing dental implants immediately into fresh extraction sockets has been reported to be as predictable as placing implants into healed sites (17). However, achieving acceptable gingival esthetics around anterior single implants and maintaining it over time can be a challenging procedure. Maintaining the integrity of the mucogingival line and avoidance of any discrepancy in relation to adjacent teeth has become a demanding task, especially when restoring teeth with previous gingival recession and/or absence of attached gingival (18).

Connective tissue graft is considered the gold standard for soft tissue coverage over immediate dental implants 
(19). However, postoperative pain and discomfort due to a second surgical site in the palate have been a major disadvantage (20).

It has been proposed that the use of the resorbable, immuno-privileged, self adhering ACM provides excellent soft tissue coverage over immediate implants and enhances the augmentation of the facial mucosa. Unlike other barrier membranes, ACM is biologically active due to the presence of stem cells and growth factors (GF) that hasten granulation tissue formation and act as a bioactive matrix that facilitates cell migration and thus wound healing (21).

Consequently, the current study was designed to evaluate clinically and histologically the soft tissue healing around immediately placed dental implants augmented with ACM versus CTG.

In the present study, significant improvement in wound healing was reported for both the ACM and the CTG groups throughout the studied healing periods. However, significant acceleration in wound healing was reported for the ACM group from two to four weeks when compared to the CTG group. Several studies have reported accelerated wound healing with the use of amniotic membrane ACM (22-24). ACM acts as a mechanical barrier covering the wound surface and protecting the newly formed epithelium which would enhance the overall re-epithelialization process. Also, it was found that ACM contains growth factors and matrix proteins promoting the migration, adhesion, and differentiation of epithelial cells (24). In't Anker et al (26) demonstrated that the ACM contains a high number of mesenchymal stem cells having the ability to differentiate into multiple lineages including their angiogenic potential which promotes wound healing.

In the present study, comparable healing scores for both groups were obtained after one week healing period. After one month , additional significant improvement was not detected in the ACM group owing to the fact that wound healing and maturation took place at an earlier period. It is suggested that ACM gradually degrades within one month. Limited literature however, exists on the resorption dynamics of the ACM. Several studies have confirmed membrane resorption into the wound after 2-4 weeks while other studies suggest that the membrane degrades after 7 days $(27,28)$.

Concerning the keratinized mucosal thickness (KMT) Ghahroudi et al (29) found that the amnion allograft was equally efficient as the connective tissue graft in increasing the thickness of the gingival tissues, while covering denuded root surfaces. In the present study an increase in the KMT was realized in the group treated with the ACM that accounted for 34\% increase in thickness at 1 month and decreased to a $26 \%$ increase at 3 months. On the other hand in the control group there was a decrease of $2.78 \%$ in the KMT which continued to decrease to $6.48 \%$ at 3 months. Suresh and Gupta (30) also reported the ACM to be efficient in biotype enhancement and increasing the KMT due to the presence of type I, III, IV, V and VII collagen in the ACM in addition to laminins and fibronectins (31).

The keratinized mucosal width (KMW) significantly decreased in both the test and the control groups. A mild recession was observed in both the test and control groups (within our clinical expectations) and all patients were fully satisfied with the esthetic results. The mucogingival junction remained stable in both groups relative to the adjacent teeth. The decrease in the KMW (mild recession) in the test and control groups may be attributed to the fact that implants placed immediately into fresh extraction sockets usually exhibit a degree of marginal bone loss due to alveolar socket remodeling. Thin buccal plates are usually more susceptible to the adverse effects of marginal bone loss and soft tissue recession (32). Chen et al (33) demonstrated that sites with thinner facial bone underwent significantly more vertical resorption than sites with thicker facial bone. Several studies have been reported on the frequency of recession at immediate implant sites. In a controlled study comparing immediate implants with implants placed 12 weeks after extraction, recession of 1 $\mathrm{mm}$ was found in seven of 23 immediate sites , compared to four of 25 12-week healed sites. Recession of 1 to $2 \mathrm{~mm}$ was observed in two of 23 immediate sites, but not in the 12-week healed group (34).

Ghahroudi et al (29) reported a mean increase in keratinized gingival width by $0.68 \pm 0.366 \mathrm{~mm}$ and $0.95 \pm 0.333 \mathrm{~mm}$ with ACM and subepithelial connective tissue graft groups, respectively in covering denuded roots. However, Oates et al (35) and Cordioli et al (36) emphasized the positive role of the subepithelial connective tissue graft in increasing the keratinized gingival width attributing to its ability to induce epithelial cell differentiation at the recipient site. Regarding the ACM, the presence of keratinocyte growth factor promotes keratinization of epithelial cells and helps the mucogingival junction to maintain its position, which explains the efficacy of the ACM in inducing keratinization. Since the positive role of both ACM and connective tissue graft in inducing keratinization and increasing the width of the keratinized gingiva is well documented, the decrease noticed in the current study may be attributed to the marginal bone loss after immediate implant placement.

Histological evaluation of soft tissue samples revealed adequate wound healing with mature tissue for both the control and the test groups. Samples showed varying degrees of maturation, connective tissue thickness, inflammation and vascularization mostly in favor of the ACM group.

The oral mucosa of the study group showed parakeratinized gingival epithelium; this finding is in agreement with Albana (2013 ) (24)who reported that the oral mucosa consists of the same normal epithelial structure Concerning the control group, our examination of the oral mucosa showed a parakeratinized gingival epithelium, keratinized gingival epithelium that consisted of stratified squamous epithelium .The keratinized pattern represents a protective layer to the underlying epithelium. The epithelium showed, epithelial rete pegs, with loose connective tissue papillae running to a long distance in the alveolar mucosa near to the keratinous surface increasing nutrition and blood supply to the epithelium. These findings are consistent to those by Lewis et al in 2005 (37).

Maturation and proliferation of the oral epithelium are inline with the increase in loads and function that are applied on to it . Studies reported high rate of turnover of the cells of the oral epithelium, the cells undergoing mitosis in the basal layer and eventually migrating to the free surface. The basal cells move away from the basal layer perpendicularly and towards the surface of the epithelium to be desquamated (38).

In the ACM group the connective tissue showed densely arranged thick bundles of collagen fibers in the reticular 
layer for the mucoperiosteal junction making the gingival mucosa immobile and firm. Similar findings were reported by Laugerette et al (39).

In both groups, inflammatory cell infiltration was observed in the connective tissue. Inflammatory cells continually migrate into and pass between the epithelial cells. This was mentioned by Schroeder, 2012 who reported that the connective tissue supporting the epithelium, even in clinically normal circumstances, shows an inflammatory cell population such as polymorphonuclear leukocytes and T-lymphocytes (38).

Numerous blood vessels were observed distributed in the underlying connective tissue. This marked increase in blood supply in this region could be considered as a response to the ACM's role in regulation of angiogenesis due to the presence of Laminin-5 (8). This increase in the blood supply suggests marked increase in the metabolic activity which probably led to active cell proliferation and high rate of turnover (40).

\section{CONCLUSION}

The present study proved that the use of ACM was very effective in covering immediately placed dental implants and enhancing wound healing. The ACM offered comparable results to the connective tissue graft concerning mucosal width, with better results regarding the mucosal thickness, healing and angiogenesis. Thus, it was concluded that ACM can be a valid alternative to connective tissue grafts for covering immediate dental implants, preserving the width of the keratinized mucosa and maintaining the integrity of the mucogingival line.

\section{CONFLICT OF INTEREST}

The authors declare that they have no conflicts of interest.

\section{REFERENCES}

1. Hämmerle CH, Chen ST, Wilson TG Jr. Consensus statements and recommended clinical procedures regarding the placement of implants in extraction sockets. Int J Oral Maxillofac Implants. 2004;19:26-8.

2. Wilson TG, Jr, Schenek R, Buser D, Cochran D. Implants placed in immediate extraction sites: a report of histologic and histometric analysis of human biopsies. Int J Oral Maxillofac Implants. 1998;13:333-41.

3. Edel A. The use of a connective tissue graft for closure over an immediate implant covered with an occlusive membrane. Clin Oral Implants Res. 1995;6:60-5.

4. Tsuda H, Rungcharassaeng K, Kan JY, Roe P, Lozada JL, Zimmerman G. Peri-implant tissue response following connective tissue and bone grafting in conjunction with immediate single-tooth replacement in the esthetic zone: A case series. Int J Oral Maxillofac Implants. 2011;26:427-36.

5. Celletti R, Davarpanah M, Etienne D, Pecora G, Tecucianu JF, Djukanovic D, et al. Guided tissue regeneration around dental implants in immediate extraction sockets: Comparison of e-PTFE and a new titanium membrane. Int J Periodontics Restorative Dent. 1994;14:243-53.

6. Bourne G. The foetal membranes. A review of the anatomy of normal amnion and chorion and some aspects of their function. Postgrad Med J. 1962;38:193201.
7. Steinberg AD, LeBreton G, Willey R, Mukherjee S, Lipowski J. Extravascular clot formation and platelet activation on variously treated root surfaces. J Periodontol. 1986;57:516-22.

8. Holtzclaw D, Toscano N. Amnion chorion allograft barrier: Indications and techniques update. JIACD. 2012;4:25-38.

9. Holtzclaw DJ, Toscano NJ. Amnion-chorion allograft barrier used for guided tissue regeneration treatment of periodontal intrabony defects: A retrospective observational report. Clin Adv Periodontics. 2013;3:1317.

10. Holtzclaw D, Hinze HF, Toscano N. Gingival flap attachment healing with amnion-chorion allograft membrane: A controlled, split mouth case report replication of the classic 1968 Hiatt Study. J Implant Adv Clin Dent. 2012;4:19-25.

11. American Society of Anesthesiologists. ASA physical status classification system. 2007. Available at: http://www. asahq.org/clinical/physicalstatus.htm.

12. O’Leary TJ, Drake RB, Naylor JE. The plaque control record. J Periodontol. 1972;43:38.

13. Sato N. Periodontal Surgery: a clinical atlas. 2000. 384.

14. AL-Mashhadani AM. The clinical effect of phenytoin on oral wound. Al-Rafidain Dent J. 2012;12:165-70.

15. Kotz S, Balakrishnan N, Read CB, Vidakovic B. Encyclopedia of statistical sciences. 2nd ed. Hoboken, N.J.: Wiley-Interscience; 2006.

16. Kirkpatrick LA, Feeney BC. A simple guide to IBM SPSS statistics for version 20.0. Student ed. Belmont, Calif.: Wadsworth, Cengage Learning; 2013.

17. Cooper LF, Reside GJ, Raes F, Garriga JS, Tarrida LG, Wiltfang J, et al. immediate provisionalization of dental implants placed in healed alveolar ridges and extraction sockets: a 5-year prospective evaluation. Int J Oral Maxillofac Implants 2014; 29: 709-17.

18. Covani U, Marconcini S, Galassini G, Cornelini R, Santini S, Barone A. Connective tissue graft used as a biologic barrier to cover an immediate implant. J Periodontol. 2007;78:1644-9.

19.Dawson A. The SAC Classification in Implant Dentistry. Berlin: Quintessence Publishing; 2009.

20. Tsuda H, Rungcharassaeng K, Kan JY, Roe P, Lozada JL, Zimmerman G. Peri-implant tissue response following connective tissue and bone grafting in conjunction with immediate single-tooth replacement in the esthetic zone: A case series. Int J Oral Maxillofac Implants. 2011;26:427-36.

21. Chen Z, Tortella FC, Dave JR, Marshall VS, Clarke DL, Sing G, et al. Human amnion-derived multipotent progenitor cell treatment alleviates traumatic brain injury-induced axonal degeneration. J Neurotrauma. 2009;26:1987-97.

22. Mangano FG, Mastrangelo P, Luongo F, Blay A, Tunchel S, Mangano C. Aesthetic outcome of immediately restored single implants placed in extraction sockets and healed sites of the anterior maxilla: a retrospective study on 103 patients with 3 years of follow-up. Clin Oral Implants Res. 2017;28:272-82.

23. Levine RA, Ganeles J, Gonzaga L, Kan JK, Randel H, Evans CD, et al. 10 Keys for Successful Esthetic-Zone Single Immediate Implants. Compend Contin Educ Dent. 2017;38:248-60. 
24. Albannaa RF, Hasouni M. Surgical Adhesive versus Silk Suture in Oral Incisions Closure; A Histopathoplogical Comparative Study on Rabbits. Germany: Lap Lambert Publishing; 2012.

25. Samandari MH, Adibi S, Khoshzaban A, Aghazadeh S, Dihimi P, Torbaghan SS, et al. Human amniotic membrane, best healing accelerator, and the choice of bone induction for vestibuloplasty technique (an animal study). Transplant Res Risk Manage. 2011;3:18.

26. In 't Anker PS, Scherjon SA, Kleijburg-van der Keur C, de Groot-Swings GM, Claas FH, Fibbe WE, et al. Isolation of mesenchymal stem cells of fetal or maternal origin from human placenta. Stem cells. 2004;22:1338-45.

27. Albannaa RF, Al-Dabbagh FM, Alnema MM. Histopathological evaluation of human amniotic membrane effect on early stage healing of induced defects in rabbit's oral mucosa. MDJ. 2013;10:252-8.

28. Kesting MR, Loeffelbein DJ, Classen M, SlottaHuspenina J, Hasler RJ, Jacobsen F, et al. Repair of oronasal fistulas with human amniotic membrane in minipigs. Br J Oral Maxillofac Surg. 2010;48:131-5.

29. Ghahroudi AA, Khorsand A, Rokn AR, Sabounchi SS, Shayesteh YS, Soolari A. Comparison of amnion allograft with connective tissue graft for root coverage procedures: a double-blind, randomized, controlled clinical trial. J Int Acad Periodontol. 2013;15:101-12.

30. Suresh DK, Gupta A. Gingival Biotype Enhancement and Root Coverage Using Human Placental Chorion Membrane .Clin Adv Periodontics. 2013;3:237-42.

31. Burman S, Tejwani S, Vemuganti GK, GopinathanU, Sangwan VS. Opthalmic Applications of Preserved Human Amniotic Membrane: A Review of Current Indications. Cell Tissue Bank. 2004;5:161-75.

32. Spray JR, Black CG, Morris HF, Ochi S. The influence of bone thickness on facial marginal bone response: Stage 1 placement through stage 2 uncovering. Ann Periodontol. 2000;5:119.

33. Chen ST, Darby IB, Reynolds EC. A prospective clincal study of non-submerged immediate implants: Clinical outcomes and esthetic results. Clin Oral Implants Res. 2007;18:552-62.

34. Lindeboom JA, Tjiook Y, Kroon FH. Immediate placement of implants in periapical infected sites: A prospective randomized study in 50 patients. Oral Surg Oral Med Oral Pathol Oral Radiol Endod. 2006;101:705-10.

35. Oates TW, Robinson M, Gunsolley JC. Surgical Therapies for the treatment of gingival recession. A Systematic Review. Ann Periodontol 2003;8:303-20.

36. Cordioli G, Mortarino C, Chierico A, Grusovin MG, Majzoub Z. Comparison of 2 Techniques of Subepithelial Connective Tissue Graft in the Treatment of gingival Recessions. J Periodontol 2001;72:1470-6.

37. Dr. Lewis C. Cummings, Wayne B. Kaldahl, and Edward P. Allen . Histologic Evaluation of Autogenous Connective Tissue and Acellular Dermal Matrix Grafts in Humans. Journal of Periodontology 2005 ; 76:178186

38. Schroeder HE. Biological structure of the normal giniva- preface. Department of Periodontology, Faculty of Odontology, University of Lund, Malmo, Sweden and Department or Oral Structural Biology,
Dental Institute, University of Zurich, Switzerland. Periodontol 2000 2012; 13: 7.

39. Laugerette F, Gaillard D, Passilly-Degrace P, Niot I, Besnard P. Do we taste fat? Biochimie 2007; 89: 265-9.

40. Iwata $\mathrm{T}$, Yamato $\mathrm{M}$, Tsuchioka $\mathrm{H}$, Takagi $\mathrm{R}$, Mukobata S, Washio K, et al. Periodontal regeneration with multi-layered periodontal ligament-derived cell sheets in a canine model. Biomaterials. 2009;30:2716-23. 